\title{
Kolaborasi dalam Pendidikan Vokasional: Mewujudkan Pembelajaran Teradun Melalui Teknologi Web 2.0
}

\author{
Collaboration in Vocational Education: Delivering Blended Learning \\ Through Web 2.0 Technology
}

\author{
Muhamad Azhar Stapa ${ }^{1}$, Mohamad Ibrahim², Amri Yusoff ${ }^{2}$ \\ ${ }^{1}$ Institut Aminuddin Baki, Kementerian Pendidikan Malaysia; muhamadazhar@iab.edu.my \\ ${ }^{2}$ Computing Department, Faculty of Art, Computing \& Creative Industry, Universiti Pendidikan Sultan Idris; \\ \{mohamad,amri\}@fskik.upsi.edu.my
}

\begin{abstract}
Abstrak
Kolaborasi dalam pendidikan vokasional melalui teknologi secara blended learning. Blended learning (BL) atau istilah dalam Bahasa Melayu ialah pembelajaran teradun, menggambarkan sebuah model pembelajaran hibrid di mana pendekatan pengajaran tradisional secara bersemuka dan aktiviti pembelajaran secara elektronik. Pembelajaran kolaboratif adalah satu pendekatan pendidikan untuk pengajaran dan pembelajaran yang melibatkan kumpulan pelajar bekerjasama untuk menyelesaikan masalah, tugasan, atau mencipta sesuatu. Ulasan keberkesanan pembelajaran BL melalui kolaborasi, bermula dengan konsep istilah dan kelebihan dari kaedah kolaborasi melalui teknologi Web 2.0. Kaedah pembelajaran yang terhasil dapat meningkatkan pengetahuan dan kemahiran pelajar dalam kolaborasi melalui teknologi. Kaedah pembelajaran secara BL adalah juga sebagai sebahagian dari langkah transformasi pendidikan vokasional.
\end{abstract}

Kata kunci: Pembelajaran teradun, vokasional, kolaborasi, Web 2.0, Kolej Vokasional.

\begin{abstract}
Collaboration in vocational education through technology in blended learning. Blended learning (BL) or its term in Malay language is mixed mode of learning, describing a hybrid learning model where face-to-face traditional teaching approaches and electronic learning activities. Collaborative learning is an educational approach for teaching and learning that involves a group of students working together to solve problems, tasks, or create something. BL learning effectiveness reviews through collaboration, starting with the concept of terms and advantages of collaborative methods through Web 2.0 technology. The resulting learning methods can enhance students' knowledge and skills in collaboration through technology. BL learning methods are also part of the transformational vocational education move.
\end{abstract}

Keywords: Blended learning, vocational, collaboration, Web 2.0, Kolej Vokasional. 


\section{PENGENALAN}

Teknologi e-pembelajaran amat memberangsangkan, kebanyakan universiti telah memasukkan sistem pengurusan pembelajaran (Learning Management System, LMS) seperti Blackboard dan Moodle dalam amalan pengajaran mereka (Ellis, Goodyear, Prosser, \& O`Hara, 2006; Ellis, Steed, \& Applebee, 2006; Kamla, 2012) untuk menyokong tenaga pengajar dalam menyampaikan bahan pengajaran dan pembelajaran (PdP) kepada pelajar. Terdapat beberapa sebab di sebalik usaha untuk menggabungkan ICT dalam proses pendidikan vokasional. Pertama, tekanan untuk menggunakan ICT di peringkat Kolej Vokasional (KV) yang datang dari perubahan demografi pelajar. Persekitaran 'Blended Learning' (BL) sesuai kepada pelajar yang lebih suka interaksi bersemuka dan pembelajaran dalam talian (Muhamad Azhar, Mohamad, \& Amri, 2014b).

Kedua, pembelajaran BL mempunyai potensi untuk menggalakkan pembelajaran sepanjang hayat dalam pendidikan (Hisham, Mohd Sobri, \& Hamzah, 2012). Dalam kajian kualitatif yang dilakukan oleh Hisham, Mohd Sobri, dan Hamzah (2012) mendapati pengalaman pembelajaran daripada pelajar yang mengikuti pengajian di Universiti Utara Malaysia, bahawa pembelajaran BL ini "sifat fleksibiliti" boleh menggalakkan pembelajaran sepanjang masa dan boleh berlaku di mana-mana". Kajian Masalela (2009) yang mendapati faktor-faktor yang mempengaruhi keputusan lima belas orang ahli fakulti untuk menggunakan pembelajaran BL adalah kerana ia bersifat kendiri (selfdirected), membangunkan kemahiran pemikiran kritikal dan menjadi pemikir bebas melalui kursus blended. Di samping itu juga, membangunkan kemahiran pembelajaran sepanjang hayat untuk digunakan apabila mereka meninggalkan alam persekolahan.

Ketiga, perubahan dalam pasaran untuk kaedah penyampaian pembelajaran datang dari inovasi dalam teknologi baru. Dalam kes Universiti Central Florida, sesi pengajaran di bilik darjah selama tiga jam telah digantikan dengan sesi pengajaran dalam talian selama dua jam. Universiti mampu mengendalikan pelbagai subjek dalam satu bilik darjah menggunakan teknologi infrastruktur yang ada (Dziuban \& Moskal, 2001). Kaedah yang digunakan di universiti boleh turut sama digunakan di KV. BL membolehkan KV menawarkan pelbagai subjek elektif kepada pelajar dan menjimatkan bilangan masa tenaga pengajar dalam sesi PdP.

Terdapat empat kelebihan utama menggabungkan pendekatan BL ke dalam amalan PdP vokasional: fleksibiliti masa; kekurangan pergantungan kepada kekangan masa guru; masa untuk refleksi; dan memenuhi keperluan yang berbeza dan gaya pembelajaran (Muhamad Azhar, Mohamad, \& Amri, 2014a). Generasi muda menggunakan teknologi dalam talian untuk aktiviti sosial dan maklumat mereka manakala generasi yang lebih tua begitu kurang menggunakan teknologi-teknologi ini (Judd, 2014). Tambahan pula, pelajar-pelajar melibatkan diri mereka mengikut keutamaan minat atau kebolehan (Horn \& Staker, 2015). Oleh sebab itu, pelajar di KV tidak boleh lagi melepaskan peluang pembelajaran secara BL melalui perkembangan teknologi pada masa kini. 


\section{DEFINISI PEMBELAJARAN TERADUN}

Pembelajaran pembelajaran teradun telah didefinisikan dalam beberapa cara dan pelbagai maksud. Ia digunakan secara tukar ganti dengan pembelajaran jarak jauh, pembelajaran dalam talian, epembelajaran, pengajaran bercampur, e-pembelajaran bercampur, pembelajaran hibrid dan pembelajaran fleksibel. Rajah 1, menunjukkan pembelajaran blended juga dikenali sebagai BL yang merujuk kepada suatu sistem pengajaran yang menggabungkan kaedah penyampaian yang pelbagai, termasuk yang sering digunakan secara bersemuka di dalam kelas tak segerak atau pembelajaran dalam talian secara e-pembelajaran. Ia mempunyai ciri-ciri memaksimumkan kelebihan yang terbaik daripada bersemuka dan pendidikan dalam talian (Wu, Tennyson, \& Hsia, 2010).

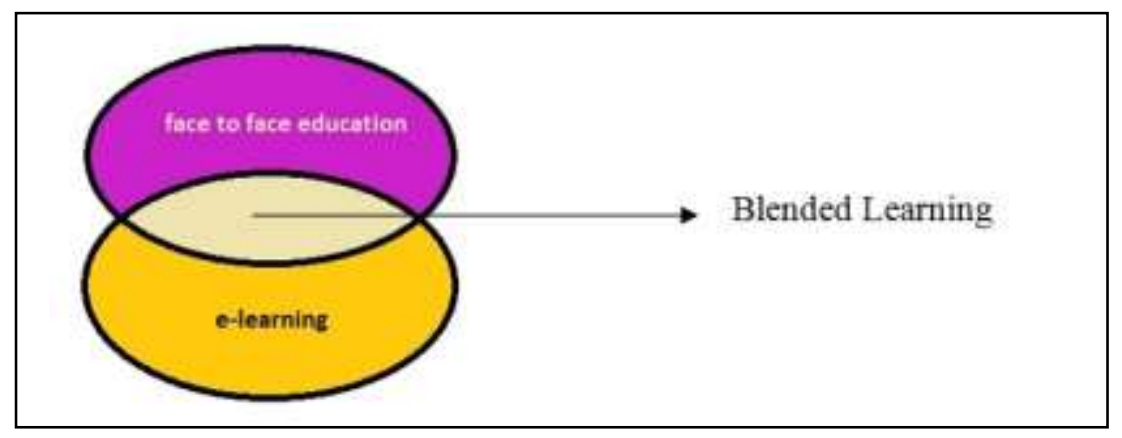

Rajah 1: Pembelajaran teradun (blended learning @ BL).

Kajian lepas mentakrifkan BL dalam pelbagai cara mengikut kaedah-kaedah pengajaran. Definisi umum didokumenkan oleh Graham, Allen dan Ure (2005) adalah dengan menggabungkan kaedah pengajaran (atau penghantaran media). Dari perspektif latihan, kemahiran dan pandangan. BL sebagai "gabungan pengajaran dalam kelas dan kaedah pembelajaran dengan pengalaman secara elektronik pengantara yang teguh". Kombinasi penghantaran berganda media yang direka untuk melengkapi antara satu sama lain dan menggalakkan pembelajaran. Merujuk kepada Jadual 1, terdapat banyak variasi dalam mendefinisikan BL dan institusi yang berbeza dalam melaksanakan pendekatan pembelajaran BL dengan cara yang berbeza. Istilah 'blended learning' yang digunakan dalam kajian ini adalah menggambarkan aktiviti pembelajaran yang melibatkan kombinasi interaksi secara bersemuka dan interaksi menggunakan teknologi ICT sebagai pengantara antara pelajar, guru dan bahan pembelajaran termasuk bahan penilaian kepada pelajar serta dikawal oleh guru.

Sebahagian besar kajian BL telah dilakukan dari konteks pembelajaran bersemuka dan aktiviti dalam talian berasaskan web. Seperti dinyatakan sebelum ini, terdapat banyak variasi dalam mentakrifkan BL dan institusi yang berbeza dalam melaksanakan pendekatan pembelajaran BL dengan cara yang berbeza. 
Jadual 1: Versi penggunaan istilah BL

\begin{tabular}{|c|c|}
\hline Penyelidik & Definisi BL \\
\hline Skill \& Young, (2002) & $\begin{array}{l}\text { Gabungan mengajar di kelas dan kaedah dengan pengalaman media elektronik untuk } \\
\text { belajar. }\end{array}$ \\
\hline $\begin{array}{l}\text { Welker \& Berardino, (2006) } \\
\text { Wai \& Seng, (2013) }\end{array}$ & $\begin{array}{l}\text { Penggunaan alat pembelajaran elektronik sebagai alat tambahan tetapi tidak } \\
\text { menggantikan pembelajaran secara bersemuka atau tradisional. }\end{array}$ \\
\hline $\begin{array}{l}\text { Kerres \& Witt, (2003) } \\
\text { Herrmann, Popyack, Char, \& } \\
\text { Zoski (2004) } \\
\text { Kaleta, Skibba, \& Joosten } \\
\text { (2007) } \\
\text { Shivetts, (2011) }\end{array}$ & $\begin{array}{l}\text { Teknologi berasaskan web kepada bersemuka untuk pembelajaran atau gabungan } \\
\text { kaedah pengajaran sebagai pembelajaran hibrid. }\end{array}$ \\
\hline $\begin{array}{l}\text { Garrison \& Kanuka, (2004) } \\
\text { Mortera-Gutiérrez, (2006) } \\
\text { Ginns, Prosser, \& Barrie, } \\
(2007) \\
\text { Fleck ,(2012) Köse, (2010) }\end{array}$ & $\begin{array}{l}\text { Menggabungkan pembelajaran dalam talian dan menerima arahan secara } \\
\text { bersemuka. }\end{array}$ \\
\hline Horn \& Staker, (2011) & $\begin{array}{l}\text { Sebagai cara pelajar boleh belajar pada bila-bila masa dengan diselia atau dikawal } \\
\text { secara tradisional atau secara jauh dari rumah melalui dalam talian yang terkawal } \\
\text { berdasarkan masa, tempat dan kadar pembelajaran. }\end{array}$ \\
\hline
\end{tabular}

\section{KELEBIHAN PEMBELAJARAN TERADUN}

Dalam BL, guru yang menggunakan LMS boleh berkongsi bahan kursus, sukatan pelajaran, pendapat dan penilaian dalam talian serta penggunaan e-mel, papan perbincangan, kalendar, blog, jurnal, bersama-sama dengan aktiviti tradisional bersemuka seperti kuliah dan tutorial. Beberapa penyelidik amat menyokong pembelajaran BL (Concannon, Flynn, \& Campbell, 2005; Maier \& Thomas, 2013; Norazah et al., 2013). BL boleh menunjukkan hala tuju guru dan pelajar secara lebih dekat dalam berkolaborasi (Graetz \& Goliber, 2002). Untuk meningkatkan hasil pembelajaran pelajar yang positif menggunakan BL, guru mesti menerima pakai teknologi baru (Yong, Fadhilah, \& Noorulsadiqin Azbiya, 2013). Jika hanya meletakkan bahan yang sedia ada dalam talian tidak memberi makna kepada pelajar. Tumpuan harus diberikan kepada mengiktiraf potensi pendekatan BL untuk meningkatkan hasil pembelajaran pelajar. Garrison dan Vaughan (2008), menyatakan bahawa BL memerlukan elemen-elemen seperti; (a) aktiviti dalam kelas yang mengandungi pautan tugasan dalam talian untuk mengukuhkan niat aktiviti di luar bilik darjah, (b) pertukaran daripada berpusatkan guru kepada pelajar- aktiviti yang tertumpu di dalam kelas dan juga talian, (c) fokus tanggungjawab kepada pelajar untuk menggunakan sumber dalam talian dan menjalankan penyelidikan dalam talian, dan (d) instrumen penilaian yang memberikan maklum balas yang kerap. 
Guru menerbitkan sumber pembelajaran mereka di LMS dan pelajar mengambil bahagian melalui Internet. Sikap positif terhadap komputer dan Internet, sebagai contoh di mana tenaga pengajar tidak takut menggunakan komputer akan menyebabkan pelajar berjaya dalam persekitaran BL (Chang, Shu, Liang, Tseng, \& Hsu, 2014). Hasil kajian mencadangkan bahawa penggunaan teknologi dalam talian di bilik darjah mampu meningkatkan pencapaian pelajar (Ibrahim \& Mehmet, 2014). Tugas guru seperti rekod pencapaian pelajar melalui skor elektronik, mengkaji bahan subjek dan berkomunikasi dengan rakan guru boleh dilaksanakan dengan lebih cekap (Rienties, Brouwer, \& Lygo-baker, 2013).

Persekitaran BL boleh menyediakan akses kepada bahan-bahan pembelajaran dalam talian untuk gaya pembelajaran yang berbeza dan melibatkan pelajar secara interaktif (Smith, 2013). Gialamas, Nikolopoulou, dan Koutromanos (2013) mendapati pendekatan BL meningkatkan pengalaman pembelajaran sebagai satu kemahiran yang membolehkan mereka untuk menangani sesuatu topik dengan sendiri dan mengatur tugasan mereka mengikut kesesuaian masa, tempat dan rakan kolaborasi. Dari pandangan kajian-kajian sebelum ini, dapat dirumuskan kenapa guru dan pelajar perlu menggunakan kaedah BL dalam PdP. Jadual 2 merumuskan alasan tersebut.

Jadual 2: Alasan pentingnya pembelajaran teradun.

\begin{tabular}{|c|c|c|}
\hline Bil & Penyelidik & Alasan dari literatur \\
\hline 1 & Aborisade, (2013) Pape, (2015) & mengembangkan kemahiran pembelajaran kendiri \\
\hline 2 & $\begin{array}{l}\text { Pape,(2015) } \\
\text { Lothridge, Fox, \& Fynan, (2013) }\end{array}$ & mengurangkan masa kelas \\
\hline 3 & Mckenzie et al., (2013) & mewujudkan persekitaran pembelajaran motivasi \\
\hline 4 & $\begin{array}{l}\text { Erdem \& Pinar, (2014) } \\
\text { Sandars, John;Murray, (2009) }\end{array}$ & melalui rangkaian sosial \\
\hline 5 & $\begin{array}{l}\text { Hung \& Chou, (2014) } \\
\text { Marco, (2013) }\end{array}$ & $\begin{array}{l}\text { mewujudkan persekitaran pembelajaran yang berpusatkan } \\
\text { kepada pelajar }\end{array}$ \\
\hline 6 & Aborisade, (2013) & $\begin{array}{l}\text { fleksibel (masa pembelajaran dan lokasi) } \\
\text { meningkatkan akses kepada bahan pembelajaran }\end{array}$ \\
\hline 7 & $\begin{array}{l}\text { Aborisade, (2013) } \\
\text { Rowe, Bozalek, \& Frantz, (2013) } \\
\text { Robert A. Ellis et al.,(2006) }\end{array}$ & menyokong kolaborasi \\
\hline 8 & $\begin{array}{l}\text { Mullamaa, (2010) } \\
\text { Mahajan \& Chaturvedi, (2013) }\end{array}$ & mencipta cara penyelesaian yang mengikut individu \\
\hline 9 & $\begin{array}{l}\text { Vernadakis, Giannousi, Derri, Michalopoulos, \& } \\
\text { Kioumourtzoglou, (2012) }\end{array}$ & mewujudkan pengajaran yang menarik \\
\hline 10 & Mullamaa, (2010) & menyokong pendekatan pengajaran bersemuka \\
\hline 11 & Robert. A. Ellis et al., (2006) & komunikasi \\
\hline
\end{tabular}

\section{PEMBELAJARAN KOLABORATIF}

Pembelajaran kolaboratif menurut Panitz dan Panitz (1998), kolaborasi adalah satu falsafah interaksi dan gaya hidup personel, bukan hanya satu teknik di dalam bilik darjah. Semua keadaan atau situasi di mana individu bersama-sama dalam kumpulan, ia menunjukkan cara untuk berurusan dengan rasa 
hormat atas kebolehan dan sumbangan pada individu lain kepada kumpulan. Manakala istilah ini dari sudut bahasa ialah "pembelajaran berkumpulan melalui percakapan dan penelitian sesama sendiri" (Dewan Bahasa dan Pustaka, 2014). Prinsip asas dalam pembelajaran kolaboratif adalah berdasarkan persetujuan melalui kerjasama dengan ahli kumpulan, ia berbeza dengan pertandingan di mana individu-individu yang terbaik dipilih dalam kumpulan tersebut.

Kaedah dan prinsip pembelajaran kolaboratif melibatkan seluruh aktiviti dalam kumpulan yang mana pelajar bekerja bersama-sama di dalam atau di luar sesi pembelajaran. Ia boleh menjadi mudah dan tidak formal sebagai kumpulan yang bekerja bersama-sama dalam proses berfikir dan berkongsi, di mana pelajar menerima soalan secara individu serta membincangkan idea-idea mereka dengan pelajar yang lain untuk membentuk jawapan yang terbaik dan kemudian berkongsi keputusan mereka dengan seluruh kelas. Penggunaan kumpulan boleh diperkenalkan pada bila-bila masa semasa kelas untuk menangani soalan-soalan atau menyelesaikan masalah atau mencipta pelbagai persembahan di dalam kelas. Bagi proses pembelajaran yang lebih berstruktur dalam kolaboratif ia juga merujuk kepada pembelajaran koperatif yang dinyatakan oleh Johson dan Johnson (1999). Banyak unsurunsur pembelajaran koperatif digunakan dalam situasi kolaboratif. Kaedah Jigsaw (Aronson \& Patnoe, 2011) adalah contoh yang baik. Pelajar-pelajar menjadi "pakar" tentang konsep dan bertanggungjawab untuk mengajar kepada ahli kumpulan yang lain. Kumpulan akan pecahkan topik besar kepada sub topik dan ahli-ahli bekerja bersama-sama dengan ahli dari kumpulan lain yang mempunyai topik yang sama. Mereka kemudian kembali kepada kumpulan asal mereka dan menerangkan topik mereka. Kejayaan pelaksanaan strategi pembelajaran kolaboratif adalah banyak bergantung kepada perancangan untuk mengharunginya, lebih banyak individu yang bekerjasama dalam kumpulan maka kejayaan lebih besar akan tercapai (Panitz \& Panitz, 1998).

Kolaboratif secara dalam talian adalah perkara yang menjadi satu topik hangat dalam dunia pendidikan pada masa kini. Pembelajaran kolaboratif mempunyai banyak istilah pada masa kini dengan adanya teknologi yang baru dalam bidang pendidikan. Menurut Gözde Girgin, (2011) aktiviti kolaboratif yang dijalankan di dalam kelas dengan menggunakan Web 2.0 kepada pelajar telah dapat mewujudkan laman web mereka sendiri, bukan sahaja boleh memberi peluang kepada pelajar untuk meluahkan perasaan, tetapi juga membantu mereka untuk melangkah ke hadapan dalam proses mendapat keyakinan diri. Pelajar-pelajar bukan sahaja akan menjadi pencipta laman web, tetapi juga mereka akan mempunyai peranan dalam memberikan maklum balas yang bermakna dengan cara menilai dan memberi tindak balas kepada rakan-rakan mereka. Oleh itu, pelajar-pelajar akan berada di dalam rangkaian proses PdP, mereka perlu terlibat dalam tugas dan memerhatikan apa yang orang lain lakukan pada masa yang sama. Kajian yang dijalankan menunjukkan bahawa sistem pembelajaran secara kolaboratif boleh dibuat lebih cekap jika ia dipertingkatkan dengan alat pembelajaran kolaboratif yang lebih terkini (Mohammad, Norshakila, Mohamad Syazli, \& Abdul Karim, 2014; Munkhchimeg \& Sanjaasuren, 2013). Untuk mencapai matlamat ini, selain daripada termasuk guru berorientasi interaktif, kita perlu dapat menangani perbezaan pelajar, mengintegrasikan aktiviti berpusatkan pelajar, pembelajaran secara menyelesaikan masalah, kadar interaksi yang tinggi dibina dari segi hubungan, refleksi dan penilaian, serta kerjasama pembangunan 
pengetahuan (Béres, Magyar, \& Turcsányi-szabó, 2012).

Elemen kolaborasi dalam talian bagi kajian ini merupakan perkara asas dalam prototaip Voclearning. Setiap pelajar mampu menyumbang kepada pencapaian bersama. Pembelajaran kolaboratif dianggap sebagai "suatu kejayaan" jika ia dapat dicapai sepenuhnya sepenuhnya (Johnson \& Johnson, 2009).

\section{TEKNOLOGI WEB 2.0 BAGI KOLABORASI}

Penggunaan Web 2.0 teknologi untuk BL diguna pakai untuk pelbagai aspek pembelajaran pelajar. Oleh kerana pelajar masih di dalam kelas tradisional mereka menerima semua arahan secara bersemuka tetapi juga mendapat manfaat daripada pembelajaran dalam talian. Salah satu komponen kebaikan pembelajaran BL adalah sifat pembelajaran kolaboratif. Apabila pelajar menggunakan perbincangan forum, wiki, atau blog, mereka bekerjasama dengan rakan-rakan mereka untuk matlamat pembelajaran yang sama. Kerjasama dalam kumpulan menarik minat pelajar (Oblinger \& Oblinger, 2006) kerana mereka menikmati aspek sosial belajar dalam kumpulan. Di samping itu, pembelajaran BL dengan teknologi Web 2.0 amat kondusif untuk pembelajaran sosial di mana mereka berinteraksi dengan rakan-rakan dengan membaca sumbangan pelajar lain. BL juga menyumbang kepada konstruktivisme. Pelajar membina pengetahuan dan pengalaman mereka sendiri dan berkongsi dengan orang lain berdasarkan apa yang mereka pelajari. Salah satu ciri yang paling penting dalam Web 2.0 adalah penyertaan dan sumbangan oleh pengguna, pelajar dapat mengambil bahagian dalam pembelajaran kerana mereka menyumbang kepada pengetahuan yang pelbagai. Oleh demikian, pelajar juga dapat membuat refleksi terhadap pembelajaran mereka dan memindahkan pengetahuan kepada situasi kehidupan sebenar.

Pelajar perlu menggunakan Web 2.0 sebagai mekanisme pembelajaran yang membantu mereka dalam memperoleh kemahiran abad ke-21. Satu contoh kemahiran pembelajaran abad ke-21 melalui pembelajaran dalam talian adalah kaedah mencari dan menyusun atur maklumat yang diperoleh. Tagging adalah satu proses teknologi Web 2.0 yang membolehkan pengguna untuk tag laman di mana mereka berminat (Asselin \& Moayeri, 2011). Walau bagaimanapun, kemahiran abad ke-21 yang paling ketara perlu kepada pelajar apabila belajar secara aktif melalui teknologi Web 2.0 adalah kemahiran bekerjasama atau berkolaborasi antara mereka. Menurut Hargadon (2010), penggunaan Web 2.0 dalam pendidikan adalah satu bentuk rangkaian pendidikan kerana pelajar terlibat dalam menyumbang, bekerjasama dan mencipta pembelajaran serta pengetahuan di kalangan mereka.

Kerjasama atau kolaborasi adalah asas teknologi Web 2.0. Mostmans, Vleugels, dan Bannier, (2012) menerangkan pembelajaran kolaboratif yang disokong oleh komputer atau Computer-Supported Collaborative learning (CSCL) sebagai satu kaedah di mana pelajar belajar bersama-sama melalui komputer dan Internet. Kolaboratif yang disokong oleh ICT dapat mengurangkan tekanan semasa proses pembelajaran berlaku. Pelajar belajar melalui interaksi dengan orang lain dan mereka tidak keseorangan apabila belajar sesuatu topik yang baru. 
Nilai pedagogi teknologi Web 2.0 bagi pembelajaran termasuklah penyertaan, perbincangan, kreativiti, minat mendalam, ekspresi diri, keterbukaan, dan kolaborasi (Hargadon, 2010). Ramai penyelidik mendapati pelbagai manfaat dalam penggunaan Web 2.0 di dalam kelas atau sebaliknya. Holcomb dan Beal (2010) mendapati bahawa Web 2.0 boleh memecahkan halangan antara kaum dan status ekonomi, serta memenuhi minat, rasa ingin tahu, dan kreativiti pelajar. Faedah lain yang boleh daripada Web 2.0 dalam kelas termasuklah bekerjasama dengan rakan-rakan, komunikasi meningkat antara bersemuka di kelas, dan maklum balas daripada guru dan rakan pelajar dari kolej lain (Archambault, Wetzel, Foulger, \& Kim Williams, 2010).

Kajian oleh Cash, Lee, dan Frass, (2010) mendapati ada guru-guru mengatakan bahawa komunikasi dengan pelajar-pelajar mereka meningkat, sejak daripada Web 2.0 digunakan. Komunikasi dengan semua pelajar adalah amat penting kerana pelajar yang biasanya tidak mengambil bahagian di dalam kelas tradisional mampu untuk mengambil bahagian dalam talian. Apabila berkomunikasi melalui Web 2.0, pelajar yang tidak takut menyatakan pendapat mereka (Bargh, McKenna, \& Fitzsimons, 2002). Dalam kelas secara bersemuka, ramai pelajar mungkin malu untuk menyumbang kepada perbincangan. Walau bagaimanapun, dalam talian ia tidak mengancam. Kajian Chao, Parker dan Fontana, (2011) mendapati bahawa pembelajaran melalui Web 2.0 meningkatkan kerjasama penglibatan dan penyertaan pelajar. Kajian (Archambault et al., 2010), juga mendapati bahawa peranan guru beralih kepada fasilitator kerana pelajar bertanggungjawab dalam pembelajaran mereka sendiri. Web 2.0 memudahkan pembelajaran berpusatkan pelajar (Archambault et al., 2010; Korkmaz \& Karakus, 2009; Sanden \& Darragh, 2011). Pelajar dapat bertanggungjawab ke atas pembelajaran mereka sendiri dan belajar pada kadar kemampuan mereka sendiri, dan Web 2.0 menggalakkan pembelajaran sepanjang hayat.

Light (2012) mencadangkan bahawa kejayaan dalam melaksanakan BL melalui Web 2.0 teknologi di sekolah-sekolah bergantung pada banyak faktor. Penunjuk pertama kejayaan adalah memperoleh maya perisian persekitaran pembelajaran seperti Blackboard, Edmondo, Schoology, Moodle, atau Drupal (Light, 2012). Sistem yang telah dibuat untuk kegunaan pendidikan adalah penting, dan ia adalah penting untuk menggunakan sesuatu yang telah bekerja untuk sekolah-sekolah lain. Sesetengah guru mungkin keberatan untuk menggunakan teknologi yang tidak dikenali; mereka tidak berani seperti pelajar-pelajar mereka. Oleh itu, adalah penting untuk menyokong untuk Web 2.0 dan mesra pengguna kebolehan mereka (Light, 2012). Guru-guru yang berpengalaman perlu membuat gembar-gembur tentang bagaimana amat mudahnya untuk menggunakan Web 2.0. Di samping itu, guru-guru perlu dilatih dan diberikan sokongan susulan (Cash et al., 2010; Heirdsfield, Walker, Tambyah, \& Beutel, 2011; Light, 2012). Guru juga harus dibenarkan untuk menyesuaikan kelas maya mereka sendiri yang khusus kepada keperluan mereka dan keperluan pelajar mereka (Light, 2012). Akhirnya, (Light, 2012) mencadangkan bahawa komunikasi harus kekal terbuka antara guru dan pelajar kerana beliau mendapati pelajar dan guru-guru yang terlibat dalam perbualan pendidikan dalam talian kerap berlaku. 
Kehadiran aplikasi Web 2.0 dilihat sebagai revolusi untuk menyebarkan maklumat dan pandangan individu secara bebas dan terbuka. Menurut Yu et al. (2011), Web 2.0 dicipta oleh Dale Dougherty pada tahun 2004. Beliau merupakan naib presiden di sebuah syarikat pengkomputeran iaitu O'Reilly Media Inc. Menurut beliau, Web 2.0 merupakan sebuah jaringan yang merangkumi pelbagai makna termasuk pengguna boleh menghasilkan kandungan dan berkongsi data serta maklumat. Web 2.0 menawarkan komunikasi yang bersifat dua arah. Maksud dari sistem komunikasi dua arah adalah pemilik memberikan informasi, kemudian pengunjung boleh memberi komen atau menambah sesuatu di dalamnya. Dengan kata lain Web 2.0 sebagai web "read-write" (Wikipedia, 2015).

Menurut Tim Berners Lee iaitu seorang pencipta web, Web 2.0 merupakan pengganti atau satu inovasi kepada Web 1.0 (Berners-Lee, Hendler, \& Lassila, 2001). Perbezaan antara Web 1.0 dan Web 2.0 adalah dari segi kepenggunaan, fungsi dan pemilikan pengguna. Web 2.0 merupakan satu ruang yang interaktif, dinamik dan fleksibel di mana pengguna boleh menyesuaikan kehendak dan idea mereka seiring dengan fungsi yang terdapat dalam Web 2.0 serta menjadikan pengguna bukan sahaja sebagai pengunjung malah turut menjadi pemilik kepada Web 2.0 tersebut (Rodrigues, Sabino, \& Zhou, 2011). Menurut Borders (2009), media sosial tidak bermula dengan komputer. Ia lahir dari maksud "line" dalam penggunaan telefon. Telefon dan rangkaian telefon telah memulakan momentum yang besar pada era 1950's. Web 2.0 melepaskan gelombang aplikasi yang memudahkan pembelajaran dengan memanfaatkan rangkaian sosial dan saluran tidak formal. Aplikasi tersebut merupakan sebahagian penting daripada strategi pembelajaran mana-mana institusi pendidikan pada masa kini dan akan datang.

\section{Rangkaian Sosial}

Rangkaian sosial adalah sebuah laman web yang membolehkan pengguna untuk membina satu ikatan sosial secara dalam talian bagi berkomunikasi dan berkongsi idea, aktiviti, gambar, minat, dan maklumat lain (Donde, Chopade, \& P. V., 2012; Hampton, Goulet, Rainie, \& Purcell, 2011). Beberapa contoh laman rangkaian sosial popular termasuk Facebook, Instagram, Twitter, LinkedIn, dan YouTube. Rangkaian sosial membenarkan pengguna untuk berkomunikasi dengan ramai orang pada satu masa yang sama. Sesetengah laman rangkaian sosial mempunyai ciri-ciri privasi yang mengehadkan siapa yang boleh melihat kandungan seseorang, tetapi laman web lain adalah untuk awam iaitu sesiapa sahaja boleh lihat.

Donde et al. (2012) menggariskan pro dan kontra untuk laman rangkaian sosial. Laman rangkaian sosial adalah kondusif untuk meluaskan jaringan sosial dengan kenalan dari pelosok dunia, dan bertemu dengan kenalan baru dengan minat yang sama. Kaedah komunikasi dalam rangkaian sosial terbuka kepada pelbagai medium, seperti mesej, gambar, dan video. Akhir sekali, laman rangkaian sosial memudahkan jaringan rangkaian individu dalam aktiviti sosial. Orang ramai boleh berkomunikasi dengan berkongsi pemikiran dan idea-idea, serta mempromosikan diri mereka sendiri, perkhidmatan, perniagaan, dan lain-lain.

Terdapat juga kontra untuk laman rangkaian sosial, seperti privasi, keselamatan, ketulenan, dan 
jenayah. Apabila rangkaian sosial berkongsi maklumat peribadi, orang yang tidak berkenaan boleh mengambil peluang ke atas maklumat tersebut. Sesetengah orang juga boleh membuat akaun palsu atas sebab-sebab manipulatif. Di samping itu, banyak kes jenayah yang boleh dilakukan dalam laman rangkaian sosial termasuk, penipuan, kecurian, gangguan dan buli.

Pada tahun 2011, 8 daripada 10 pelajar terlibat secara aktif dalam rangkaian sosial seperti Facebook atau MySpace (Lenhart et al., 2011). Menurut eBizMBA (2014), Facebook adalah laman web rangkaian sosial yang paling popular pada bulan Oktober 2014, dengan kira-kira 900 juta pengguna bulanan. Walaupun, ia adalah laman rangkaian sosial yang paling popular, Facebook mungkin tidak sesuai sebagai alat untuk pendidikan kerana atas pelbagai faktor dan alasan. Burhanna, Seeholzer dan Salem (2009) mendapati pelajar mengambil berat tentang penggunaan Facebook tetapi mereka bimbang terhadap maklumat peribadi dan aktiviti mereka. Pelajar mendakwa bahawa sesiapa sahaja boleh membuka akaun Facebook, dan ia bukan sangat peribadi. Bagaimanapun, mereka mendakwa bahawa portal sekolah mereka adalah lebih selamat dan bebas dari persekitaran luar. Pelajar lebih suka menjalankan aktiviti pembelajaran dalam talian melalui portal sekolah kerana ia selamat (Burhanna et al., 2009). Pada asasnya, pelajar menyuarakan bahawa mereka lebih suka untuk mempunyai perbezaan yang jelas antara rangkaian sosial dan pendidikan. Mereka tidak mahu menggunakan laman rangkaian sosial untuk pendidikan formal (Wodzicki, Schwämmlein, \& Moskaliuk, 2012).

Dalam satu kajian terhadap pelajar perubatan yang menggunakan Facebook untuk belajar, Gray, Annabell dan Kennedy (2010) mendapati bahawa Facebook adalah mudah memotivasikan pelajar tetapi tidak memberi faedah akademik yang berkaitan dengan penggunaannya. Ramai golongan pendidik menyuarakan kebimbangan tentang penggunaan rangkaian sosial untuk sesi pembelajaran kerana ia terlalu tidak formal (Chao, Parker, \& Fontana, 2011; Asselin \& Moayeri, 2011). Ada juga perasaan bimbang bahawa rangkaian sosial akan mengganggu pendidikan tradisional (Donde et al., 2012). Laman seperti Facebook boleh mengaburkan garisan antara pendidikan dan sosialisasi atau di antara guru dan pelajar, perlu di beri perhatian penting oleh sekolah (Gray et al., 2010).

Rangkaian sosial untuk pendidikan adalah rangkaian pembelajaran kerana rangkaiannya bukan semata-mata untuk interaksi sosial tetapi untuk tujuan pendidikan (Holcomb, Brady, \& Smith, 2010). Dalam satu kajian yang dijalankan oleh (Archambault et al., 2010), 80\% daripada guru-guru percaya bahawa penggunaan laman rangkaian pendidikan meningkat pencapaian pelajar. Adalah penting untuk laman rangkaian pendidikan di struktur dengan baik supaya semua orang mengetahui tujuannya adalah untuk pendidikan dan bukan bersosial (Gray et al., 2010). Apa bila digunakan dengan sebaik mungkin, terdapat banyak faedah yang boleh didapati daripada laman rangkaian pendidikan. Laman rangkaian pendidikan amat sesuai untuk bertukar-tukar fikiran, maklumat praktikal dan akademik, membawa kepada kerjasama dalam pembelajaran di sekolah (Selwyn, 2009). 
Chao dan rakan-rakan (2011) mendapati bahawa laman rangkaian pendidikan dapat meningkatkan penglibatan pelajar, penyampaian bahan pembelajaran yang lebih baik, dan mencipta komuniti pembelajaran ke arah satu matlamat yang sama. Pelajar dapat melihat nota pembelajaran sebelum dan selepas sesi bersemuka di kelas, menjawab kuiz secara dalam talian, dan berkomunikasi dengan rakan-rakan mereka untuk bertanya soalan dan menyelesaikan secara bersama (Chao et al., 2011).

\section{Perbincangan Dalam Talian}

Berkomunikasi dengan individu lain adalah salah satu faktor yang paling ketara dalam teknologi Web 2.0 dan rangkaian sosial. Perbincangan dalam talian adalah satu contoh penggunaan teknologi Web 2.0 di mana pelajar boleh berbincang dengan guru-guru atau rakan-rakan sekelas dan berkongsi idea dalam talian. Selalunya ini disebut sebagai forum (Bishop \& Doiron, 2003), di mana guru boleh menghantar soalan atau topik untuk sesi perbincangan. Walaupun guru yang memuat naik sesuatu soalan dalam talian, pelajar juga mampu untuk menghantar soalan dalam perbincangan mereka. Taranto, Dalbon, dan Gaetano (2011) mendapati kebanyakan perbincangan dalam talian didorong oleh pelajar, bukannya guru. Guru sebenarnya menjadi peserta dalam banyak perbincangan dalam talian yang menimbulkan tahap berfikir untuk semua yang terlibat (Grisham \& Wolsey, 2006). Mewujudkan pembelajaran berpusatkan kepada pelajar seperti forum perbincangan dalam talian, dipermudahkan dengan teknologi Web 2.0.

Ruday (2011) mencadangkan bahawa perbincangan dalam talian perlu bagi meningkatkan aktiviti kelas dan perbincangan secara bersemuka. Perbincangan dalam talian tidak harus menggantikan perbincangan yang diadakan di dalam kelas tradisional tetapi harus menjadi kesinambungan perbincangan dalam kelas. Oleh kerana tidak ada kekangan masa, mereka mempunyai lebih banyak masa untuk perbincangan secara mendalam, dan setiap pelajar mempunyai peluang bagi menyumbang kepada perbincangan.

Vesisenaho et al. (2010) mendapati perbincangan dalam talian memudahkan dalam persekitaran BL amat bermakna kerana mereka membenarkan guru untuk melihat hasil kefahaman pelajar, walaupun digunakan semasa bersemuka pada sesi kelas pengajaran. Di samping itu, perbincangan dalam talian membolehkan pelajar meneruskan perbincangan di luar kelas. Menurut kajian oleh Taranto et al. (2011), pelajar menyatakan bahawa setiap orang mendapat peluang untuk bercakap dalam talian, yang tidak selalu berlaku di dalam kelas. Kebiasaannya pelajar tidak mempunyai masa yang cukup untuk setiap orang menyumbang dalam perbincangan kelas tradisional, dan tidak semua pelajar merasa selesa untuk berkongsi di hadapan kelas. Walau bagaimanapun, dalam perbincangan dalam talian, pelajar lebih cenderung untuk berkomunikasi kerana mereka tidak takut di hadapan seluruh kelas (Mccarthy, 2010). Tiada siapa yang boleh melihat mereka dalam talian. Perbincangan dalam talian juga jujur (Grisham \& Wolsey, 2006; Ruday, 2011) kerana pelajar tidak takut untuk berkongsi idea-idea dan perasaan sebenar mereka. 
Di samping itu, pembelajaran secara dalam talian dapat menjadikan pelajar lebih berwawasan dan berfikiran terbuka kerana mereka mempunyai masa untuk merancang respons mereka (Grisham \& Wolsey, 2006; Ruday, 2011). Jawapan atau respons pelajar juga boleh menjadi lebih kreatif daripada dalam kelas tradisional. Pelajar sering digalakkan untuk menghantar post topik menggunakan teks multimedia (Ruday, 2011) atau simbol dan ikon berbentuk emosi (Grisham \& Wolsey, 2006) bagi meningkatkan pemikiran mereka. Grisham dan Wolsey (2006) juga mendapati bahawa pelajar mungkin merasa tekanan untuk menulis dengan baik dalam talian kerana begitu ramai orang akan melihat post mereka. Pelajar mungkin lebih menyedari struktur ayat, tatabahasa, kandungan, perbendaharaan kata dan ejaan kerana pelajar-pelajar lain akan mengkritik jawapan mereka (Shih, 2011). Mengkritik respon atau jawapan antara satu sama lain adalah bermanfaat kerana pelajar dapat mendengar perspektif setiap rakan sekelas (Ruday, 2011), ada yang jawapan mereka tidak pernah dipertimbangkan sebelum. Di samping itu, mungkin juga terdapat tekanan kepada pelajar untuk bersaing dengan lebih membaca kandungan pelajaran supaya jawapan yang diberikan lebih tepat kerana respon jawapan mereka akan dilihat oleh seluruh kelas dan bukan hanya guru sahaja. Tambahan pula, guru boleh melihat tindak balas setiap pelajar, dan boleh menggunakan jawapan sebagai penilaian formatif kepada hasil pembelajaran (Ruday, 2011).

Penilaian formatif adalah penting untuk menyokong pembelajaran pelajar kerana dapat menyemak hasil pembelajaran pelajar sepanjang masa pembelajaran (Shepard, 2006). Guru kemudian boleh membuat keputusan jika sesuatu pelajaran perlu dikaji semula, atau jika pelajar mempunyai pemahaman yang kurang dalam topik pembelajaran. Penilaian formatif, yang mudah dan berkesan dilaksanakan menggunakan perbincangan dalam talian, adalah salah satu intervensi pengajaran yang paling berkuasa untuk meningkatkan pencapaian pelajar (Shepard, 2006).

Shroff dan Vogel (2009), menjalankan kajian ke atas kesan pembelajaran BL, melalui perbincangan dalam talian menggunakan Blackboard platform, bagi memberi motivasi kepada pelajar. Mereka diukur melalui kecekapan motivasi, cabaran, maklum balas, pilihan, minat pelajar dan rasa ingin tahu. Kajian mendapati bahawa terdapat beberapa perbezaan dalam motivasi pelajar apabila belajar dalam persekitaran BL. Pelajar lebih bersemangat untuk mengambil bahagian dalam perbincangan dalam talian daripada perbincangan secara bersemuka (Shroff \& Vogel, 2009; Smith, 2013). Rumusan dari kajian ini ialah kompetensi pelajar yang menyertai perbincangan dalam talian telah meningkatkan hasil pembelajaran mereka. Tidak seperti perbincangan bersemuka, pelajar-pelajar ini merasakan mereka telah mengambil bahagian dalam perbincangan kerana mereka mahu, dan mereka juga merasakan mahir dan mampu memberi sumbangan dalam perbincangan mereka secara dalam talian. Pada tahun 2010, Shroff dan Vogel menerus penyelidikan mereka mengenai minat pelajar semasa menggunakan pembelajaran BL. Mereka merasakan bahawa minat pelajar adalah petunjuk utama kepada motivasi, yang meningkatkan penyertaan, dan juga secara positif dikaitkan dengan pencapaian pelajar. Walaupun keputusan mereka menunjukkan perbezaan yang signifikan di antara kepentingan perbincangan dalam talian melalui pembelajaran BL dan perbincangan secara bersemuka di dalam kelas tradisional, Shroff dan Vogel (2010) telah memerhatikan bahawa pelajar lebih bersemangat untuk mengambil bahagian dalam perbincangan dalam talian daripada bersemuka 
di dalam kelas. Mereka mendapati pelajar lebih teruja menyertai kelas maya menggunakan aplikasi dalam talian.

\section{KESIMPULAN}

Persekitaran semasa pendidikan vokasional memerlukan pertimbangan yang teliti terhadap peranan BL dalam menangani isu-isu yang berkaitan dengan PdP seperti perbezaan generasi, jenis personaliti dan gaya pembelajaran. Matlamat kajian ini adalah untuk menunjukkan aktiviti kolaborasi melalui teknologi dalam pembelajaran secara BL bagi pendidikan vokasional dapat dicapai dengan perkembangan teknologi pada hari ini. Tidak kira apa teori, penyelidik bersetuju bahawa pelajar belajar secara berbeza pada hari ini berbanding daripada masa lalu. Selain itu, pelajar memerlukan kemahiran yang berbeza untuk berjaya dalam abad ke-21. Kemahiran Abad ke-21 bersama-sama dengan pengetahuan mata pelajaran teras, pelajar juga memerlukan kemahiran untuk pemikiran kritis, penyelesaian masalah, komunikasi, dan menjalin kerjasama antara mereka. Kemahiran dalam teknologi, literasi media, ICT adalah kritikal bagi membina kejayaan abad ke-21. Dalam usaha untuk mengajar kemahiran yang diperlukan, untuk memotivasikan diri pelajar kepada keutamaan pembelajaran vokasional. Pelajar menikmati teknologi baru kerana mereka membesar menggunakannya. Mereka selesa dengan menggunakan pelbagai teknologi Web 2.0 dan rangkaian sosial, dan mereka mahu melihat diri mereka diintegrasikan ke dalam dunia pembelajaran.

\section{RUJUKAN}

Aborisade, P. A. (2013). Blended learning in English for Academic Purposes courses : A Nigerian case study. In B. Tomlinson \& C. Whittaker (Eds.), Blended Learning in English Language Teaching: Course Design and Implementation (pp. 3542). London, UK: British Council.

Archambault, L., Wetzel, K., Foulger, T. S., \& Kim Williams, M. (2010). Professional Development 2.0: Transforming Teacher Education Padagogy with 21 Century Tools. Journal of Digital Learning in Teacher Education, 27(February 2015), 4-11. http://doi.org/10.1080/21532974.2010.10784651

Aronson, E., \& Patnoe, S. (2011). Cooperation in the Classroom: The Jigsaw Method (3rd ed.). London: Pinter \& Martin, Ltd. Asselin, M., \& Moayeri, M. (2011). The Participatory Classroom : Web 2.0 in the Classroom. Literacy Learning: The Middle Years, 19(2), i-vii.

Bargh, J. A., McKenna, K. Y. A., \& Fitzsimons, G. M. (2002). Can you see the real me? Activation and expression of the "true self" on the Internet. Journal of Social ..., 58(1), 33-48. Retrieved from http://onlinelibrary.wiley.com/doi/10.1111/1540-4560.00247/full

Béres, I., Magyar, T., \& Turcsányi-szabó, M. (2012). Towards a Personalised, Learning Style Based Collaborative Blended Learning Model with Individual Assessment. Informatics in Education, 11(1), 1-28.

Berners-Lee, T., Hendler, J., \& Lassila, O. (2001). The Semantic Web. Scientific American, 284(5), $28-27$.

Bishop, G. D., \& Doiron, G. (2003). Using Online Forums as a Replacement for Face-to-Face Discussion Groups. In Proceedings of the FASS - CDTL Symposium: Grounded Experiences in University Teaching and Learning. (pp. 3643). Singapore: Centre for Development of Teaching and Learning.

Borders, B. (2009). A Brief History of Social Media.

Burhanna, K. J., Seeholzer, J., \& Salem Jr., J. (2009). No Natives Here: A Focus Group Study of Student Perceptions of Web 2.0 and the Academic Library. The Journal of Academic Librarianship, 35(6), 523-532. http://doi.org/10.1016/j.acalib.2009.08.003

Cash, J. C., Lee, D. E., \& Frass, L. R. (2010). Web 2.0: Using Internet Resources To Increase Student Achievement Among High School Students In Rural Schools. Journal of Information Systems Technology \& Planning, 3(6), 73-80.

Chang, C., Shu, K., Liang, C., Tseng, J., \& Hsu, Y. (2014). Is Blended e-Learning as Measured by an Achievement Test and 
Self-Assessment Better than Traditional Classroom Learning for Vocational High School Students ? The International Review of Research in Open and Distance Learning, 15(2), 213-231.

Chao, J. T., Parker, K. R., \& Fontana, A. (2011). Developing an Interactive Social Media Based Learning Environment. Issues in Informing Science and Information Technology, 8, 323-334.

Concannon, F., Flynn, A., \& Campbell, M. (2005). What campus-based students think about the quality and benefits of elearning. British Journal of Educational Technology, 36(3), 501-512. http://doi.org/10.1111/j.1467-8535.2005.00482.x

Dewan Bahasa dan Pustaka. (2014). Kamus Dewan Edisi Keempat. Retrieved December 11, 2014, from http://prpm.dbp.gov.my/Search.aspx?k=kolaboratif

Donde, D. S., Chopade, N., \& P. V., R. (2012). Social networking sites: A new era of 21 st century. SIES Journal of Management, 8(1), 66-73.

Dziuban, C., \& Moskal, P. (2001). Evaluating Distributed Learning at Metropolitan Universities. Communication Studies, (4), $60-61$.

eBizMBA. (2014). Top 15 Most Popular Social Networking Sites | October 2014. Retrieved October 1, 2014, from http://www.ebizmba.com/articles/social-networking-websites

Eda Gözde, G. (2011). A Web 2.0 Tool for Language Teaching with Flash Content. Procedia Computer Science, 3, 627-631. http://doi.org/10.1016/j.procs.2010.12.105

Ellis, R. A., Goodyear, P., Prosser, M., \& O’Hara, A. (2006). How and what university students learn trough online and face to face discussion: conceptions, intentions and approaches. Journal of Computer Assisted Learning, 22,. Journal of Computer Assisted Learning, 22, 244-256.

Ellis, R. A., Steed, A. F., \& Applebee, A. C. (2006). Teacher conceptions of blended learning, blended teaching and associations with approaches to design. Australasian Journal of Educational Technology, 22(3), 312-335. http://doi.org/10.4103/0974-620X.60017

Erdem, M., \& Pinar, N. K. (2014). Students' Opinions On Facebook Supported Blended Learning Environment. The Turkish Online Journal of Educational Technology, 13(1), 199-206.

Fleck, J. (2012). Blended learning and learning communities: opportunities and challenges. Journal of Management Development, 31(4), 398-411. http://doi.org/10.1108/02621711211219059

Garrison, D. R., \& Kanuka, H. (2004). Blended learning: Uncovering its transformative potential in higher education. Internet and Higher Education, 7(2), 95-105. http://doi.org/10.1016/j.iheduc.2004.02.001

Garrison, D. R., \& Vaughan, N. D. (2008). Blended Learning in Higher Education: Framework, Principles, and Guidelines. San Francisco, CA: John Wiley \& Sons.

Gialamas, V., Nikolopoulou, K., \& Koutromanos, G. (2013). Student Teachers' Perceptions About the Impact of Internet Usage on Their Learning and Jobs. Computers \& Education, 62, 1-7. http://doi.org/10.1016/j.compedu.2012.10.012

Ginns, P., Prosser, M., \& Barrie, S. (2007). Students' perceptions of teaching quality in higher education: the perspective of currently enrolled students. Studies in Higher Education, 32(5), 603-615. http://doi.org/10.1080/03075070701573773

Graetz, K. a., \& Goliber, M. J. (2002). Designing collaborative learning places: Psychological foundations and new frontiers. New Directions for Teaching and Learning, 2002(92), 13-22. http://doi.org/10.1002/tl.75

Graham, C. R., Allen, S., \& Ure, D. (2005). Benefits and challenges of blended learning environments. In Encyclopedia of Information Science and Technology (pp. 253-259).

Gray, K., Annabell, L., \& Kennedy, G. (2010). Medical students' use of Facebook to support learning: insights from four case studies. Medical Teacher, 32(12), 971-6. http://doi.org/10.3109/0142159X.2010.497826

Grisham, D. L., \& Wolsey, T. D. (2006). Recentering the Middle School Classroom as a Vibrant Learning Community: Students, Literacy, and Technology Intersect. Journal of Adolescent \& Adult Literacy, 49(8), 648-660. http://doi.org/10.1598/JAAL.49.8.2

Hampton, K. N., Goulet, L. S., Rainie, L., \& Purcell, K. (2011). Social networking sites and our lives. Washington, DC. Retrieved from http://pewinternet.org/Reports/2011/Technology-and-social-networks.aspx

Hargadon, S. (2010). Educational Networking. Multimedia \& Internet@ Schools, 17(2), 10-16.

Heirdsfield, A., Walker, S., Tambyah, M., \& Beutel, D. (2011). Blackboard as an online learning environment: What do teacher education students and staff think? Australian Journal of Teacher Education, 36(July), 1-16.

Herrmann, N., Popyack, J., Char, B., \& Zoski, P. (2004). Assessment of a course redesign: introductory computer programming using online modules. ACM SIGCSE Bulletin, (March), 3-7. Retrieved from http://dl.acm.org/citation.cfm?id=971326

Hisham, D., Mohd Sobri, D. @ A. W., \& Hamzah, A. R. (2012). Blended learning (BL) As pedagogical alternative to teach business communication course: Case study of UUM executive diploma program. Turkish Online Journal of Distance Education, 13(July), 297-315.

Holcomb, L. B., \& Beal, C. M. (2010). Capitalizing on Web 2.0 in the Social Studies Context. TechTrends, 54(4), $28-32$.

Holcomb, L. B., Brady, K. P., \& Smith, B. V. (2010). The Emergence of "Educational Networking": Can Non-commercial, Education-based Social Networking Sites Really Address the Privacy and Safety Concerns of Educators? Journal of Online Learning and Teaching, 6(2), 475-481. Retrieved from http://jolt.merlot.org/vol6no2/holcomb_0610.pdf?utm_source=twitterfeed\&utm_medium=twitter 
Horn, M. B., \& Staker, H. (2011). The Rise of K-12 Blended Learning. Innosight Institute. San Mateo, CA. Retrieved from www.innosightinstitute.org

Horn, M. B., \& Staker, H. (2015). Blended: Using Disruptive Innovation to Improve Schools (1st ed.). San Francisco, CA: Jossey-Bass A Wiley Brand.

Hung, M.-L., \& Chou, C. (2014). Students' perceptions of instructors' roles in blended and online learning environments: A comparative study. Computers \& Education. http://doi.org/10.1016/j.compedu.2014.10.022

Ibrahim, Y. K., \& Mehmet, D. (2014). Effect of Blended Learning Environment Model on High School Students' Academic Achievement. The Turkish Online Journal of Educational Technology, 13(1), 78-87.

Johnson, D. W., \& Johnson, R. T. (2009). An Educational Psychology Success Story: Social Interdependence Theory and Cooperative Learning. Educational Researcher, 38(5), 365-379. http://doi.org/10.3102/0013189X09339057

Johson, D. W., \& Johnson, R. T. (1999). Making Cooperative Learning Work. Theory into Practice, 38(2), 67-73. Retrieved from http://www.ccsstl.com/sites/default/files/Cooperative Learning Research .pdf

Judd, T. (2014). Making sense of multitasking: The role of Facebook. Computers \& Education, 70, 194-202. http://doi.org/10.1016/j.compedu.2013.08.013

Kaleta, R., Skibba, K., \& Joosten, T. (2007). Discovering, Designing and Delivering Hybrid Courses. In A. G. Picciano \& C. D. Dziuban (Eds.), Blended Learning Research Perspectives. Needham, MA: The Sloan Consortium. Retrieved from http://elab.learningandteaching.dal.ca/dalblend2013-files/blended-learning-research-perspectives-book.pdf\#page=122

Kamla, A. A.-B. (2012). Learners ' Perspective on Critical Factors to LMS Success in Blended Learning : An Empirical Investigation Learners ' Perspective on Critical Factors to LMS Success in Blen ded Learning: An Empirical Investigation Perspective on Critical Factors LMS in B. Communication of The Association for Information Systems, 30(January), 11-34.

Kerres, M., \& Witt, C. De. (2003). A Didactical Framework for the Design of Blended Learning Arrangements. Journal of Educational Media, 28(2-3), 101-113. http://doi.org/10.1080/1358165032000165653

Korkmaz, O., \& Karakus, U. (2009). The Impact of Blended Learning Model on Student Attitudes towards Geography Course and Their Critical Thinking Dispositions and Levels. Turkish Online Journal of Educational Technology- ..., 8(4), 5163. Retrieved from http://eric.ed.gov/?id=EJ859497

Köse, U. (2010). A Blended Learning Model Supported with Web 2.0 Technologies. Procedia Social and Behavioral Sciences, 2, 2794-2802. http://doi.org/10.1016/j.sbspro.2010.03.417

Lenhart, A., Madden, M., Smith, A., Purcell, K., Zickuhr, K., \& Rainie, L. (2011). Teens, kindness and cruelty on social network sites. Pew Internet and American Life Project. Retrieved from http://scholar.google.com/

Light, D. (2012). Principals for Web 2.0 Success. 10 ways to build vibrant learning communities with the read/write web. Learning and Leading with Technology, (July), 18-20.

Lothridge, K., Fox, J., \& Fynan, E. (2013). Blended learning: efficient, timely and cost effective. Australian Journal of Forensic Sciences, 45(4), 407-416. http://doi.org/10.1080/00450618.2013.767375

Mahajan, T., \& Chaturvedi, S. (2013). Impact Study of Blended Learning on Functional Effectiveness Factor of Managerial Effectiveness. Journal of Management Research, 13(4), 209-218.

Maier, T. a., \& Thomas, N. J. (2013). Hospitality Leadership Course Design and Delivery: A Blended-Experiential Learning Model. Journal of Hospitality \& Tourism Education, 25(1), 11-21. http://doi.org/10.1080/10963758.2013.777585

Marco, F. (2013). Drawer: An innovative teaching method for blended learning. Federated Conference on Computer Science and Information Systems, 727-734. Retrieved from http://ieeexplore.ieee.org/xpls/abs_all.jsp?arnumber=6644089

Masalela, R. K. (2009). Potential Benefits and Complexities of Blended Learning In Higher Education : The case of the University of Botswana. Turkish Online Journal of Distance Education, 10(1), 66-83.

Mccarthy, J. (2010). Blended learning environments : Using social networking sites to enhance the first year experience. Australasian Journal of Educational Technology, 26(6), 729-740. Retrieved from http://www.ascilite.org.au/ajet/ajet26/mccarthy.html

Mckenzie, W. A., Perini, E., Rohlf, V., Toukhsati, S., Conduit, R., \& Sanson, G. (2013). A Blended Learning Lecture Delivery Model for Large and Diverse Undergraduate Cohorts. Computers \& Education, 64, 116-126. http://doi.org/10.1016/j.compedu.2013.01.009

Mohammad, A., Norshakila, M. R., Mohamad Syazli, F., \& Abdul Karim, M. (2014). Cloud Computing as a Construction Collaboration Tool for Precast Supply Chain M. Jurnal Teknologi, 70(7), 1-7.

Mortera-Gutiérrez, F. (2006). Faculty best practices using blended learning in e-learning and face-to-face instruction. International Journal on E-Learning, 5(3), 313-337. Retrieved from http://www.editlib.org/

Mostmans, L., Vleugels, C., \& Bannier, S. (2012). Raise Your Hands or Hands-on? The Role of Computer-Supported Collaborative Learning in Stimulating Intercreativity in Education. Educational Technology \& Society, 15(4), 104-113.

Muhamad Azhar, S., Mohamad, I., \& Amri, Y. (2014a). Engaging Vocational College Students Through Blended Learning: Improving Class Attendance and Participation. In Conference proceedings of the 4th World Congress on TVET 2014 (pp. 238-246). Melaka, Malaysia: UTHM.

Muhamad Azhar, S., Mohamad, I., \& Amri, Y. (2014b). Pembangunan Model Blended Learning Menggunakan Teknologi Web 2.0 Dalam Pembelajaran Aliran Vokasional. In The 9 th International Malaysian Studies Conference (MSC9) 
(pp. 1-19). Terengganu: Malaysian Social Science Association.

Mullamaa, K. (2010). ICT in Language Learning - Benefits and Methodological Implications. International Education Studies, 3(1), 38-44.

Munkhchimeg, B., \& Sanjaasuren, B. (2013). Control possibility of students $\mathfrak{€}^{\mathrm{TM}}$ learning process through using Learning Management System. In Strategic Technology (IFOST), 2013 8th International Forum (pp. 395-399). Ulaanbaatar: IEEE.

Norazah, M. N., Rozniza, Z., Mohd Hanafi, M. Y., Rosseni, D., Mohamed Amin, E., \& Maimun Aqsha, L. (2013). ICT in Educational for Deaf Learners: Teacher' Perspective. Research Journal of Applied Sciences, 8(2), 103-111.

Oblinger, D., \& Oblinger, J. (2006). Is It Age or IT : First Steps Toward Understanding the Net Generation. California School Library Association Journal, 29(2), 8-16.

Panitz, T., \& Panitz, P. (1998). Encouraging the use of collaborative learning in higher education. In J. J. F. Forest (Ed.), University Teaching: International Perspectives (2013th ed., p. 488). New York: Routledge. Retrieved from https://books.google.com/books?id=WfVRAwAAQBAJ\&pgis=1

Pape, L. (2015). Developing courses that combine face-to-face and virtual instruction in pursuit of 21st-century skills in classrooms. Retrieved April 8, 2015, from http://www.aasa.org/SchoolAdministratorArticle.aspx?id=12924

Rienties, B., Brouwer, N., \& Lygo-baker, S. (2013). The effects of online professional development on higher education teachers ' beliefs and intentions towards learning facilitation and technology. Teaching and Teacher Education, 29, 122-131. http://doi.org/10.1016/j.tate.2012.09.002

Rodrigues, J. J. P. C., Sabino, F. M. R., \& Zhou, L. (2011). Enhancing e-learning experience with online social networks. IET Communications, 5(8), 1147. http://doi.org/10.1049/iet-com.2010.0409

Rowe, M., Bozalek, V., \& Frantz, J. (2013). Using Google Drive to facilitate a blended approach to authentic learning. British Journal of Educational Technology, 44(4), 594-606. http://doi.org/10.1111/bjet.12063

Ruday, S. (2011). Expanding the possibilities of discussion: A strategic approach to using online discussion boards in the middle and high school English classroom. Contemporary Issues in Technology and Teacher Education, 11(4), 350 361. Retrieved from http://www.citejournal.org/vol11/iss4/languagearts/article2.cfm

Sandars, John;Murray, C. (2009). Reflective learning for the next generation. In I. L. C. Terry T. Kidd (Ed.), Wired for Learning:an educator's guide to web 2.0 (1st ed., pp. 153-168). USA: Information Age Publishing.

Sanden, S., \& Darragh, J. (2011). Wiki Use in the 21 st Century Literacy Classroom: A Framework for Evaluation. Contemporary Issues in Technology and Teacher Education, 11, 6-20. Retrieved from http://www.editlib.org/p/35420

Selwyn, N. (2009). Faceworking: exploring students' education-related use of Facebook. Learning, Media and Technology, 34(July 2014), 157-174. http://doi.org/10.1080/17439880902923622

Shepard, L. A. (2006). Classroom Assessment. In R. L. Brennan (Ed.), Educational Measurement (4th ed., pp. 623-646). Westport, CT: Praeger Publishers.

Shih, R. (2011). Can Web 2.0 technology assist college students in learning English writing? Integrating Facebook and peer assessment with blended learning. Australasian Journal of Educational Technology, 27, 829-845. Retrieved from http://ascilite.org.au/ajet/ajet27/shih.html

Shivetts, C. (2011). E-Learning and Blended Learning: The Importance of the Learner : A Research Literature Review. International Jl. on E-Learning, 10(3), 331-337.

Shroff, R. H., \& Vogel, D. R. (2009). Assessing the factors deemed to support individual student intrinsic motivation in technology supported online and face-to-face discussions. Journal of Information Technology Education, 8. Retrieved from http://libir1.ied.edu.hk/dspace/handle/2260.2/498

Shroff, R. H., \& Vogel, D. R. (2010). An investigation on individual student's perceptions on interest utilizing a blended learning approach. International Journal on E-Learning, 9(2), 279-294.

Skill, T. D., \& Young, B. A. (2002). Embracing the hybrid model: Working at the intersections of virtual and physical learning spaces. New Directions for Teaching and Learning, (92), 23-32.

Smith, N. V. (2013). Face-to-face vs . blended learning: Effects on secondary students ' perceptions and performance. Procedia - Social and Behavioral Sciences, 89, 79-83. http://doi.org/10.1016/j.sbspro.2013.08.813

Taranto, G., Dalbon, M., \& Gaetano, J. (2011). Academic Social Networking Brings Web 2 . 0 Technologies to the Middle Grades. Middle School Journal, 42(5), 12-19.

Vernadakis, N., Giannousi, M., Derri, V., Michalopoulos, M., \& Kioumourtzoglou, E. (2012). The impact of blended and traditional instruction in students' performance. Procedia Technology, 1, 439-443. http://doi.org/10.1016/j.protcy.2012.02.098

Vesisenaho, M., Valtonen, T., Kukkonen, J., Havu-nuutinen, S., Hartikainen, A., \& Karkkainen, S. (2010). Blended learning with everyday technologies to activate students' collaborative learning. Science Education International, 21(4), 272283.

Wai, C. C., \& Seng, E. L. K. (2013). Measuring the effectiveness of blended learning environment: A case study in Malaysia. Education and Information Technologies. http://doi.org/10.1007/s10639-013-9293-5

Welker, J., \& Berardino, L. (2006). Blended Learning: Understanding The Middle Ground Between Traditional Classroom And Fully Online Instruction. Journal of Educational Technology System, 34(1), 33-55. 
Wikipedia. (2015). Web 2.0.

Wodzicki, K., Schwämmlein, E., \& Moskaliuk, J. (2012). “Actually, I Wanted to Learn”: Study-related Knowledge Exchange on Social Networking Sites. The Internet and Higher Education, 15, 9-14. http://doi.org/10.1016/j.iheduc.2011.05.008

Wu, J.-H., Tennyson, R. D., \& Hsia, T.-L. (2010). A study of student satisfaction in a blended e-learning system environment. Computers \& Education, 55(1), 155-164. http://doi.org/10.1016/j.compedu.2009.12.012

Yong, H. A., Fadhilah, M. Y., \& Noorulsadiqin Azbiya, Y. (2013). Communication In Learning Management System (LMS): The Impact On Student Learning Satisfaction. Prosiding Simposium Pengurusan Teknologi, Operasi \& Logistik, (Siptik V), 10-11.

Yu, M., Yuen, A. H. K., Park, J., Lam, H. C., Lau, K. K., \& Lau, W. (2011). Web 2.0 Divide among Naughty insiders, Worried Outsiders, and Invisible Monitors: A Case Study. In Communications in Computer and Information Science (Vol. 177 CCIS, pp. 51-62). http://doi.org/10.1007/978-3-642-22383-9_5 